\title{
Detection of DNA of filariae closely related to Mansonella perstans in faecal samples from wild non-human primates from Cameroon and Gabon
}

Colette Marie Gaillard', Sebastien David Pion', Hadjira Hamou' , Constant Sirima', Charlotte Bizet', Thomas Lemarcis ${ }^{1}$, Jules Rodrigues², Amandine Estebann', Martine Peeters ${ }^{1}$, Eitel Mpoudi Ngole ${ }^{3}$, Illich Mombo ${ }^{4}$, Florian Liégeois ${ }^{5}$, Coralie Martin², Michel Boussinesq ${ }^{1}$ and Sabrina Locatelli ${ }^{1 *}$

\begin{abstract}
Background: The Onchocercidae is a family of filarial nematodes with several species of medical or veterinary importance. Microfilariae are found in the blood and/or the dermis and are usually diagnosed in humans by microscopy examination of a blood sample or skin biopsy. The main objectives of this study were to evaluate whether filariae DNA can be detected in faecal samples of wild non-human primates (NHPs), whether the detected parasites were closely related to those infecting humans and whether filarial DNA detection in faeces is associated with co-infections with nematodes (Oesophagostumum sp. and Necator sp.) known to cause blood loss while feeding on the host intestinal mucosa.

Methods: A total of 315 faecal samples from 6 species of NHPs from Cameroon and Gabon were analysed. PCRs targeted DNA fragments of cox 1 and 125 rDNA genes, to detect the presence of filariae, and the internal transcribed spacer 2 (ITS2), to detect the presence of Oesophagostomum sp. and Necator sp. infections.

Results: Among the 315 samples analysed, 121 produced sequences with $>90 \%$ homology with Onchocercidae reference sequences. However, $63 \%$ of the $12 \mathrm{~S}$ rDNA and $78 \%$ of the cox 1 gene sequences were exploitable for phylogenetic analyses and the amplification of the 125 rDNA gene showed less discriminating power than the amplification of the cox 1 fragment. Phylogenetic analyses showed that the cox 1 sequences obtained from five chimpanzee DNA faecal samples from Gabon and two from Cameroon cluster together with Mansonella perstans with high bootstrap support. Most of the remaining sequences clustered together within the genus Mansonella, but the species could not be resolved. Among the NHP species investigated, a significant association between filarial DNA detection and Oesophagostomum sp. and Necator sp. infection was observed only in gorillas.

Conclusions: To our knowledge, this is the first study reporting DNA from Mansonella spp. in faecal samples. Our results raise questions about the diversity and abundance of these parasites in wild life, their role as sylvatic reservoirs and their potential for zoonotic transmission. Future studies should focus on detecting variants circulating in both human and NHPs, and improve the molecular information to resolve or support taxonomy classification based on morphological descriptions.
\end{abstract}

Keywords: Mansonella spp., Anthropoids, Phylogeny, Africa, Faeces, Gastro-intestinal worms, Zoonosis

*Correspondence: sabrina.locatelli@ird.fr

1 IRD UMI 233-INSERM U1175, University of Montpellier, Montpellier, France

Full list of author information is available at the end of the article

c) The Author(s) 2020. This article is licensed under a Creative Commons Attribution 4.0 International License, which permits use, sharing, adaptation, distribution and reproduction in any medium or format, as long as you give appropriate credit to the original author(s) and the source, provide a link to the Creative Commons licence, and indicate if changes were made. The images or other third party material in this article are included in the article's Creative Commons licence, unless indicated otherwise in a credit line to the material. If material is not included in the article's Creative Commons licence and your intended use is not permitted by statutory regulation or exceeds the permitted use, you will need to obtain permission directly from the copyright holder. To view a copy of this licence, visit http://creativeco mmons.org/licenses/by/4.0/. The Creative Commons Public Domain Dedication waiver (http://creativecommons.org/publicdomain/ zero/1.0/) applies to the data made available in this article, unless otherwise stated in a credit line to the data. 


\section{Background}

Onchocercidae nematodes form a family of parasitic worms comprising eight subfamilies and 88 genera [1, 2]. Species belonging to genera such as Loa, Onchocerca, Wuchereria, Brugia and Mansonella are responsible for human or animal diseases such as loiasis, onchocerciasis or lymphatic filariasis. Some of these species are found in both humans and non-human primates (NHPs) [2]. The diagnosis of filariasis is typically based on the detection of the adult stage of the parasite or, more often, of the larval stages produced by adult female worms, called microfilariae (mf). Several diagnostic methods are available to detect these parasites in humans. If one considers the main species parasitizing humans, $\mathrm{mf}$ are detected by light microscopy examination of a blood sample (Loa loa, Wuchereria bancrofti, Brugia malayi and Mansonella perstans), or of a skin biopsy (Onchocerca volvulus and M. streptocerca), or both (M. ozzardi) [3]. In addition to blood and dermis, $\mathrm{mf}$ can sometimes be found in the urine. Besides the microscopical identification of the parasites, various other techniques detecting antigens, antibodies or parasitic DNA are also available and used either for the individual diagnosis or to assess the infection endemicity levels in communities.

Molecular diagnostic methods, based on the amplification of parasite DNA by polymerase chain reaction (PCR) methods [4], or by loop-mediated isothermal amplification (LAMP) [5-7] have the advantages of being more sensitive in detecting parasites than the usual microscopy methods, especially in case of low $\mathrm{mf}$ densities, as well as increased certainty in the identification to the species or even strain level $[2,8]$.

In the early 2010s, it was observed that Plasmodium DNA could be found in NHP faeces [9], despite the fact that these are blood-borne parasites. Similar results reporting detectable amounts of $P$. falciparum DNA in the faeces of infected humans have been recently reported $[10,11]$. However, the mechanisms underlying how Plasmodium DNA ends up in the faeces remain unclear. These observations led us to the question of whether PCR techniques could also effectively detect filarial DNA in faecal samples.

The first goal of this study was to investigate the possibility to find filarial infections from DNA extracted from faecal samples of six species of NHPs living in forest regions of Cameroon and Gabon: the gorilla (Gorilla gorilla gorilla), the chimpanzee (Pan troglodyte troglodytes), the mandrill (Mandrillus sphinx), the collared mangabey (Cercocebus torquatus torquatus, also known as red-capped mangabey), the agile mangabey (Cercocebus agilis) and the greater spot-nosed monkey (Cercopithecus nictitans). Secondly, we performed phylogenetic analysis of the filarial DNA fragments found in the faeces of these NHPs, as well as filarial DNA fragments identified in humans to characterise and compare the species. For these purposes, PCRs were carried out by targeting DNA fragments of mitochondrial (12S ribosomal DNA and cytochrome $c$ oxidase subunit 1 ( $\operatorname{cox} 1)$ genes, followed by Sanger sequencing to discriminate parasite species. Lastly, and consequent to the successful amplification of filarial mitochondrial DNA in faeces, we investigated whether DNA presence was associated with co-infections with strongylid nematodes including hookworms $[12,13]$. These parasites can cause significant blood loss when adults attach themselves to the intestinal mucosa and while feeding [14]. Despite the absence of impact of strongylid infections on the detection of Plasmodium spp. in faeces of western lowland gorillas and eastern chimpanzees [15], their presence and resulting bleeding in the intestine would be a plausible explanation for the detection of filarial DNA in faeces. Therefore, we ran nested PCRs targeting the internal transcribed spacer 2 (ITS2) to look for the presence of infections with Oesophagostomum sp. and Necator sp. to infer whether there was a positive association between these parasites and the detection of filarial DNA in faeces.

\section{Methods}

\section{Study sites and faecal collection methods}

A total of 315 faecal samples from wild-living, nonhabituated NHPs were analysed. These samples were collected non-invasively around NHP nests, feeding places, or on traces at four study sites: the forests surrounding the villages of Djoum (DJ) $\left(2^{\circ} 40^{\prime} 00^{\prime \prime} \mathrm{N}, 12^{\circ}\right.$ $\left.40^{\prime} 00^{\prime \prime} \mathrm{E}\right)$, Mambélé-Lobeké National Park (MB/LB) $\left(2^{\circ} 25^{\prime} 00^{\prime \prime} \mathrm{N}, 15^{\circ} 24^{\prime} 00^{\prime \prime} \mathrm{E}\right)$ and Somalomo (SL) (3 ${ }^{\circ} 23^{\prime}$ $00^{\prime \prime} \mathrm{N}, 12^{\circ} 44^{\prime} 00^{\prime \prime} \mathrm{E}$ ) in Cameroon (collections between 2008 and 2010), and in remote primary forests and secondary forests surrounding the village of Matakamangoye II $\left(0^{\circ} 6^{\prime} 30^{\prime \prime} \mathrm{S}, 13^{\circ} 41^{\prime} 57^{\prime \prime} \mathrm{E}\right.$, Gabon (collections between 2009 and 2013) (Fig. 1). These samples were characterized and analysed in previous studies to determine the prevalence and genetic diversity of simian immunodeficiency viruses (SIV) $[16,17]$. Faecal samples were identified to be of likely chimpanzee, gorilla or Cercopithecidae monkey origin by experienced trackers and/or by the researchers. A 15-20 g sample was then placed into a $50 \mathrm{ml}$ tube and mixed with an equal amount of RNAlater ${ }^{\circledR}$ (Ambion, Austin, TX, USA). The date, time, and location (longitude and latitude provided by global positioning system, GPS) of sample collection were recorded along with the collector's name. Faecal samples were generally kept at ambient temperature for no longer than 2 weeks and subsequently stored at $-20{ }^{\circ} \mathrm{C}$ once back in Yaoundé, Cameroon, or Franceville, Gabon. Samples were 
shipped to Montpellier, France, at ambient temperature, and then stored at $-80{ }^{\circ} \mathrm{C}$ upon reception. All samples were transported to France in full compliance with export and import regulations.

\section{DNA extraction from NHP faecal samples}

Faecal DNA was extracted using the QIAamp Stool DNA Mini Kit (Qiagen, Valencia, CA, USA) following the manufacturer's instructions. Briefly, $1.5 \mathrm{ml}$ of faecal RNAlater ${ }^{\circledR}$ mixture was re-suspended in stool lysis buffer and clarified by centrifugation. The supernatants were treated with an InhibitEx tablet, subjected to proteinase K digestion, and passed through a DNA binding column. Bound DNA was eluted in $100 \mu \mathrm{l}$ elution buffer. To investigate the presence of gastro-intestinal parasites, a modified DNA extraction protocol was adopted, after the clarification. This step consisted of an additional homogenization in tubes containing silica beads of different size (lysis matrix E) in a FastPrep-24 mill (MP Biomedical, Eschwege, Germany) and an overnight incubation at $56{ }^{\circ} \mathrm{C}$ to better expose the parasite DNA in eggs.

\section{Host species confirmation and identification of individual genotypes by microsatellite analyses}

Each NHP species and the number of individual faecal samples collected were determined in previous studies, as mentioned before. DNA was extracted from all faecal samples collected in the field and host species were confirmed by PCR amplification and sequence analysis of a 460-500-bp mitochondrial DNA fragment spanning the $12 S$ rDNA region, using methods described in previous studies [18]. To determine the number of individuals sampled, the faeces collected from gorillas and chimpanzees were subjected to microsatellite analyses, as previously described $[17,19,20]$. Samples were genotyped at seven loci in two multiplex PCRs (amplifying D18s536, D4s243, D10s676, and D9s922 or D2s1326, D2s1333 and D4s1627), and for sex determination, a region of the amelogenin gene that contains a deletion in the $\mathrm{X}$ but not the $\mathrm{Y}$ chromosome was amplified using a Taq DNA polymerase core kit (MP Biomedical, Irvine, CA, USA) with 2 to $10 \mu \mathrm{l}$ fecal DNA. Mandrills, collared and agile mangabeys and greater spot-nosed monkeys were subjected to mtDNA analyses but not to microsatellite analyses; to ascertain that we were not going to analyze more than one sample belonging to the same individual, we selected the samples among a wide range of samples previously collected and we applied discriminative criteria choices, such as exclusion of primates' territory ranges overlap and GPS coordinates of the collection locations.

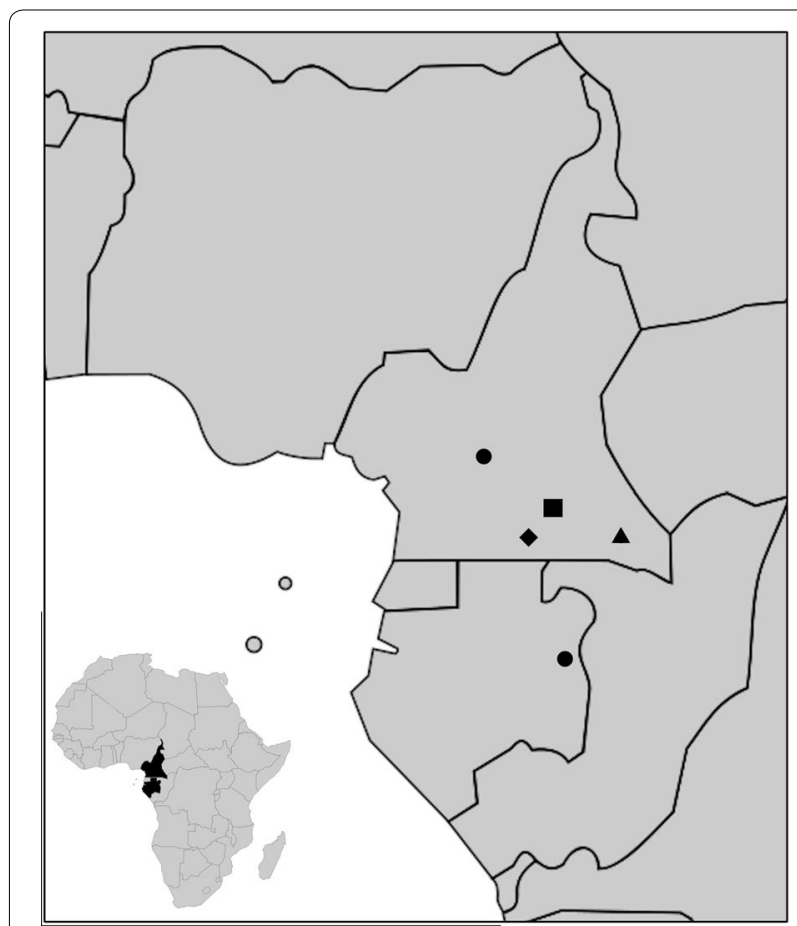

Fig. 1 Faecal samples collection sites in Cameroon and in Gabon. In Cameroon: Okola (dot), Djoum (diamond), Somalomo (square), Mambelé/Lobeké National Park (triangle); in Gabon: Matakamangoye (dot)

\section{DNA extraction from human dried blood spots (DBS)}

DBS collected from 20 human subjects with known $M$. perstans infection and living in the Okola health district (Cameroon) were shipped to Montpellier to be used as references for phylogenetic analyses [3]. DNA extraction from DBS was performed using the NucliSENS ${ }^{\circledR}$ kit (bioMérieux, Craponne, France) according to the manufacturer's instructions, as previously described [21]. DNA was eluted in $60 \mu \mathrm{l}$ buffer. The PCR reactions on the $M$. perstans mf-positive human blood samples were carried on once all other samples had been tested.

\section{PCR screening of filarial nematodes}

A DNA barcoding approach based on either the cox 1 marker or the $12 \mathrm{~S}$ rDNA marker was used to discriminate between filaroid species [2, 8, 22-24]. PCR screening of filarial DNA was based on partial sequences of two mitochondrial genes: $12 S$ rDNA (approximately 450 bp) and cytochrome $c$ oxidase subunit 1 (cox1) (c.600 bp). Amplification of the $12 S$ rDNA and cox 1 fragments was conducted according to Casiraghi et al. [25]. Primers and PCR programmes are shown in Table 1. PCRs were processed in a final volume of $50 \mu \mathrm{l}$. The amplification of the target fragments was carried out by nested PCR. Bovine serum albumin (BSA) was added at the 
final concentration of $0.2 \mu \mathrm{g} / \mathrm{ml}$ to improve amplification success. All PCR reactions were performed using the Expand Long Template PCR system (Roche Diagnostics, Indianapolis, IN, USA), according to the manufacturer's instructions. Each PCR reaction was carried out on a Bio-Rad $\mathrm{T} 100^{\mathrm{TM}}$ thermal cycler (Hercules, CA, USA) in the presence of a negative control. NHP samples were tested first in a human filaria-free environment. Once all NHP samples were tested, we proceeded with the $M$. perstans mf-positive human blood samples. Amplified fragments were visualized by horizontal electrophoresis on $1 \%$ agarose under a UV light. The PCR products of interest were subsequently purified and extracted using the GeneClean ${ }^{\circledR}$ Turbo Kit (Qbiogene Inc., Carslbad, CA, USA). Sequencing reactions were performed with the ABI PRISM ${ }^{\circledR}$ BigDye $^{\mathrm{TM}}$ Terminators Kit (Applied Biosystems, Foster City, CA, USA). DNA was then precipitated and sequenced according to the Sanger method (3500 Genetic Analyzer; Applied Biosystems, Foster City, CA, USA).

\section{PCR screening of Oesophagostomum sp. and Necator sp}

We ran a semi-nested PCR targeting fragments of the ITS2 maker to determine the presence of Oesophagostomum sp. and Necator sp. The external PCR was performed using primers $\mathrm{NC1}$ and NC2. Subsequently, a semi-nested internal PCR generating 260 to 350 bp amplicons was performed with primers NC2 and OesophITS2-21 [26-28]. Primers and PCR programs are shown in Table 1 . The PCR reaction was performed in a $50 \mu \mathrm{l}$ reaction volume containing $10 \mu \mathrm{l}$ and $5 \mu \mathrm{l}$ of template DNA for primary and semi-nested PCR, respectively, $10 \mathrm{pM}$ of each primer, $25 \mu \mathrm{l}$ HotStarTaq Master Mix (Qiagen, Courtaboeuf, France), providing a final concentration of $1.5 \mathrm{mM} \mathrm{MgCl}_{2}$ and $200 \mu \mathrm{M}$ of each dNTP. For the external PCR, bovine serum albumin (Sigma-Aldrich, St. Louis, MO, USA) was added at the final concentration of $0.2 \mu \mathrm{g} / \mathrm{ml}$ to improve amplification success. The reactions were performed on a Bio$\operatorname{Rad} \mathrm{T} 100^{\mathrm{TM}}$ thermal cycler (Bio-Rad). Primer details and PCR conditions are listed in Additional file 1: Table S1. The amplicons were electrophoresed on $1 \%$ agarose gels stained with ethidium bromide. After purification (on a $2 \%$ agarose gel) using the GeneClean ${ }^{\circledR}$ Turbo Kit (Qbiogene), the PCR products were sequenced with the primers of the second step on an automated sequencer $(3500$ Genetic Analyzer; Applied Biosystems) and the resulting sequences analysed with SeqMan DNASTAR software (Lasergene; DNASTAR, Inc., Madison, WI, USA).

\section{Molecular identification and phylogenetic analysis}

The sequences obtained were assembled, aligned and corrected manually using the SeqMan DNASTAR software (Lasergene, DNASTAR Inc., Madison, WI) and then compared against reference sequences deposited in GenBank using the Nucleotide Basic Local Alignment Search Tool (BLASTn) [29]. Sequences generated during the current study and previously published sequences from draft or complete genomes were aligned using MUSCLE 16 in MEGA 6.06, with minor

Table 1 Primers and PCR programs

\begin{tabular}{|c|c|c|c|c|c|c|c|c|c|c|c|}
\hline \multirow[t]{3}{*}{ Target organism } & \multirow[t]{3}{*}{ Gene } & \multirow[t]{3}{*}{ Primer name } & \multirow[t]{3}{*}{ Sequence $\left(5^{\prime}-3^{\prime}\right)$} & \multirow[t]{3}{*}{ Product size (bp) } & \multicolumn{7}{|c|}{ Thermal profile* } \\
\hline & & & & & \multicolumn{2}{|c|}{ Step 1} & \multicolumn{2}{|c|}{ Step 2} & \multicolumn{2}{|c|}{ Step3 } & \multirow[t]{2}{*}{$N$} \\
\hline & & & & & $\mathrm{T}$ & $\mathrm{D}$ & $\mathrm{T}$ & D & $\mathrm{T}$ & $\mathrm{D}$ & \\
\hline \multirow[t]{8}{*}{ Filariae } & \multirow[t]{4}{*}{$125 \mathrm{rDNA}$} & 12SdegF2/ & ATTACYTATTYTTAGTITA & \multirow[t]{2}{*}{$\sim 600$} & \multirow[t]{2}{*}{94} & \multirow[t]{2}{*}{30} & \multirow[t]{2}{*}{45} & \multirow[t]{2}{*}{30} & \multirow[t]{2}{*}{68} & \multirow[t]{2}{*}{45} & \multirow[t]{2}{*}{$45^{b}$} \\
\hline & & 12SnemR2 ${ }^{\mathrm{a}}$ & CTACCATACTACAACTTACGC & & & & & & & & \\
\hline & & 12SF/ & GTTCCAGAATAATCGGCTA & \multirow[t]{2}{*}{$\sim 450$} & \multirow[t]{2}{*}{94} & \multirow[t]{2}{*}{30} & \multirow[t]{2}{*}{54} & \multirow[t]{2}{*}{30} & \multirow[t]{2}{*}{68} & \multirow[t]{2}{*}{30} & \multirow[t]{2}{*}{35} \\
\hline & & $12 S d e g R$ & ATTGACGGATGRTTTGTACC & & & & & & & & \\
\hline & \multirow[t]{4}{*}{$\operatorname{cox} 1$} & FColextdF1 & TATAATTCTGTTYTDACTA & \multirow[t]{2}{*}{$\sim 970$} & \multirow[t]{2}{*}{94} & \multirow[t]{2}{*}{30} & \multirow[t]{2}{*}{45} & \multirow[t]{2}{*}{30} & \multirow[t]{2}{*}{68} & \multirow[t]{2}{*}{60} & $45^{b}$ \\
\hline & & FCo1extdR $1^{a}$ & ATGAAAATGAGCYACWACATAA & & & & & & & & \\
\hline & & COlintF/ & TGATTGGTGGTTTTGGTAA & $\sim 650$ & 94 & 30 & 54 & 30 & 68 & 45 & 35 \\
\hline & & COlintR & ATAAGTACGAGTATCAATATC & & & & & & & & \\
\hline Hook/ Nodular worms & ITS2 & $\mathrm{NC1}$ & ACGTCTGGTTCAGGGTTGTT & $\sim 900$ & 94 & 30 & 50 & 30 & 72 & 45 & 45 \\
\hline & & NC2 & TTAGTTTCTTTTCCTCCGCT & & & & & & & & \\
\hline & & OesophITS2 & TGTRACACTGTTTGTCGAAC & $250-300$ & 94 & 30 & 55 & 30 & 72 & 30 & 35 \\
\hline & & NC2 & TTAGTTTCTTTTCCTCCGCT & & & & & & & & \\
\hline
\end{tabular}

\footnotetext{
a ITS2 PCRs start with $95^{\circ} \mathrm{C}$ for 15 min and finish by $72^{\circ} \mathrm{C}$ for $10 \mathrm{~min}$; $12 \mathrm{~S} \mathrm{rDNA}$ and cox 1 PCRs start with $94^{\circ} \mathrm{C}$ for 3 min and finish with $68^{\circ} \mathrm{C}$ for 10 min

b $35 \times$ for DBS and $45 \times$ for stool samples

Abbreviations: Step 1, denaturation; Step 2, annealing; Step 3, elongation; T, temperature $\left({ }^{\circ} \mathrm{C}\right)$; $\mathrm{D}$, duration (s); N, number of cycles
} 
manual corrections [30]. Maximum Likelihood (ML) was used to infer cox 1 and $12 S$ rDNA phylogenetic trees, and were executed with 1000 bootstrap replicates in MEGA 6.06. A partitioned model was implemented to estimate evolution parameters separately for each gene. Using the corrected version of the Akaike information criterion (AIC), JModelTest analysis [31] was performed to establish the evolutionary model best adapted to the sequences alignment for each individual gene and for the concatenation of the two genes. The general time-reversible plus invariant sites plus gamma distributed model $(G T R+I+\Gamma)$ offered the best fit for cox 1 and $12 S$ rRNA. To root the trees, Filaria latala (Spirurida: Filariidae) was included as the outgroup. Molecular species delimitation was evaluated using distance-based methods. Between-groups mean distance was calculated using MEGA 6.06.

\section{Statistical analysis}

A two-tailed Fisher's exact test was used to test for deviations from the null hypothesis, which assumed that there was no association between infection with intestinal parasites and detection of filarial DNA. The tests were applied to each of the different species of NHP separately, as well as to the pooled data across all NHP species.

\section{Results}

PCR-positive results and filariae homology in cox 1 and 125 rDNA fragments from six species of non-human primates

The 315 samples of NHP faeces included 65 samples from gorillas, 12 from mandrills, 222 from chimpanzees, 9 from red-capped mangabeys, 3 from agile mangabeys and 4 from greater spot-nosed monkeys. PCRs targeting the $12 S \mathrm{rDNA}$ and $\operatorname{cox} 1$ mitochondrial genes of filariae were run for all samples selected. 12S rDNA and cox 1 sequences were also obtained from 20 human patients and 7 of them were added for comparisons to the phylogenetic trees. Among the 315 samples analysed, 121 were positive by PCR (38\%): 31 samples were positive for $12 S$ rDNA only, 59 samples were positive for cox 1 only, and 31 for both gene fragments (Table 2). The sequences obtained showed $>90 \%$ homology with reference filarial sequences available on GenBank (BLASTn). For the gorillas, sequences from 30 out of 65 samples (46\%), for the mandrills, 2 sequences out of 12 (17\%), for the chimpanzees 85 out of 222 (38\%), for the Cercocebus only 1 (agile mangabey) out of $12(8 \%)$, and for the greater spot-nosed monkeys 3 out of 4 (75\%) showed high similarities (>90\% homology) within the family Onchocercidae.

\section{Phylogenetic analyses of cox 1 and 125 rDNA gene fragments}

Among these 121 samples, 39 out of 62 sequences were exploitable for phylogenetic analyses for the $12 \mathrm{~S}$ rDNA gene (corresponding to $63 \%$ of the sequences obtained) and 70 out of 90 for the cox 1 gene (corresponding to $78 \%$ of the sequences obtained) (Table 3 ). The remaining sequences were not included in the alignments because they were of low quality (less than $250 \mathrm{bp}$ ) or displayed background noise with too many unresolved degenerated nucleotides.

Phylogenetic analyses of the 70 cox 1 gene fragments depicted a tree composed of 5 monophyletic groups (Fig. 2). At the bottom (group 5), a group of three gorilla samples clustered together with Protospirura muricula (Nematoda: Spiruridae, a parasite of murid rodents) and 3 other samples from Cercopithecus nictitans branched out of the same node. The group just above, represented exclusively by chimpanzee faecal samples from Gabon (group 4) was not very highly supported, its robustness being < 70. Therefore, it remains difficult to associate these sequences to a given species. Then, three groups (1, 2 and 3) clustered together within the genus Mansonella with a bootstrap support $>70 \%$. They all belong to the clade ONC5 as described in Lefoulon et al. [2] (Additional file 2: Figure S1). Parasite sequences from five chimpanzees from Matakamangoye (Gabon) and two chimpanzees from Somalomo (Cameroon) grouped together with $M$. perstans infecting humans from the Okola region (Cameroon) and with two $M$. perstans reference sequences infecting humans, retrieved from the GenBank (group 2). Sample homology was > 98\%. Groups 1 and 3 were composed of nematodes of the genus Mansonella infecting gorillas, chimpanzees and mangabeys from different regions (MatakamangoyeGabon, Somalomo and Mambele/Lobeke National ParkCameroon), indicating the absence of phylogeographic clusters. In cox 1 , group 1 and group 2 sequences were genetically relatively closer than groups 2 and 3 , with a mean interspecific divergence of $4.2 \%$, and $6.8 \%$ respectively. Identification of filarial species using $\operatorname{cox} 1$ as a molecular marker was accurate, as previously indicated for other filarial species [2, 8, 22]. The cox 1 divergence threshold value to discriminate between onchocercid species was previously established at 4.8\% [22]. However, depending on the dataset and the number of analysed sequences, intraspecific distances between most of the studied onchocercid species were lower than $2 \%$ and interspecific distances were higher than $4.5 \%$.

Phylogenetic analyses of the $12 \mathrm{~S}$ rDNA gene fragment showed less discriminating power compared to the analyses of the cox 1 fragment and fewer sequences were available for analysis (Fig. 3, Table 3) as observed for the analysis 
Table 2 PCR and BLASTn summary results according to NHP species and location

\begin{tabular}{|c|c|c|c|c|c|c|c|}
\hline Country & Locality & Host species & $n$ & $\begin{array}{l}\text { Positive } 125 \\
\text { rDNA }\end{array}$ & Positive cox 1 & $\begin{array}{l}\text { Positive } 125 \text { rDNA } \\
\text { and cox } 1\end{array}$ & $\begin{array}{l}\text { Positive } \\
\text { individuals }\end{array}$ \\
\hline \multirow[t]{15}{*}{ Cameroon } & \multirow[t]{5}{*}{ Djoum } & Chimpanzee & 0 & 0 & 0 & 0 & 0 \\
\hline & & Gorilla & 0 & 0 & 0 & 0 & 0 \\
\hline & & Mandrill & 12 & 2 & 0 & 0 & 2 \\
\hline & & Red-capped Mangabey & 7 & 0 & 0 & 0 & 0 \\
\hline & & Greater spot-nosed monkey & 1 & 0 & 0 & 0 & 0 \\
\hline & \multirow[t]{5}{*}{ Somalomo } & Chimpanzee & 23 & 4 & 9 & 2 & 11 \\
\hline & & Gorilla & 38 & 12 & 13 & 7 & 18 \\
\hline & & Mandrill & 0 & 0 & 0 & 0 & 0 \\
\hline & & Red-capped Mangabey & 2 & 0 & 0 & 0 & 0 \\
\hline & & Greater spot-nosed monkey & 2 & 0 & 2 & 0 & 2 \\
\hline & \multirow[t]{5}{*}{ Mambelé/ Lobeke NP } & Chimpanzee & 59 & 26 & 20 & 15 & 31 \\
\hline & & Gorilla & 27 & 4 & 8 & 0 & 12 \\
\hline & & Mandrill & 0 & 0 & 0 & 0 & 0 \\
\hline & & Agile Mangabey & 3 & 1 & 1 & 1 & 1 \\
\hline & & Greater spot-nosed monkey & 1 & 1 & 1 & 1 & 1 \\
\hline Gabon & \multirow[t]{2}{*}{ Matakamangoye } & Chimpanzee & 140 & 12 & 36 & 5 & 43 \\
\hline Total & & & 315 & 62 & 90 & 31 & 121 \\
\hline
\end{tabular}

Abbreviation: $\mathrm{n}$, individuals tested

of the genus Onchocerca [8], therefore precise species identification remains unresolved. However, 6 samples (CAM_5149, CAM_9803, CAM_9838, CAM_5158, CAM_5160 and CAM_4874) within group 1 in the cox1 phylogenetic tree, have been successfully amplified for the $12 S \mathrm{rDNA}$ fragment. Five out of these 6 samples amplified in both genes, clustered together with $M$. perstans samples infecting humans, although with a less robust bootstrap support; only sample CAM_9838, from a gorilla, branched outside this $M$. perstans group in the $12 S$ phylogenetic tree. Finally, 2 samples from Djoum in Cameroon (CAM_3337 from a mandrill and CAM_3338 from

Table 3 Summary results of positive individuals in phylogenetic trees according to NHP species and location

\begin{tabular}{|c|c|c|c|c|c|c|c|}
\hline Country & Locality & Host species & $n$ & $\begin{array}{l}\text { 12S rDNA } \\
\text { phylogeny }\end{array}$ & $\begin{array}{l}\text { cox1 } \\
\text { phylogeny }\end{array}$ & $\begin{array}{l}\text { 12S rDNA and cox1 } \\
\text { phylogeny }\end{array}$ & $\begin{array}{l}\text { Positive } \\
\text { individuals }\end{array}$ \\
\hline \multirow[t]{15}{*}{ Cameroon } & \multirow[t]{5}{*}{ Djoum } & Chimpanzee & 0 & 0 & 0 & 0 & 0 \\
\hline & & Gorilla & 0 & 0 & 0 & 0 & 0 \\
\hline & & Mandrill & 12 & 1 & 0 & 0 & 1 \\
\hline & & Red-capped Mangabey & 7 & 1 & 0 & 0 & 1 \\
\hline & & Greater spot-nosed monkey & 1 & 0 & 0 & 0 & 0 \\
\hline & \multirow[t]{5}{*}{ Somalomo } & Chimpanzee & 23 & 4 & 7 & 1 & 10 \\
\hline & & Gorilla & 38 & 11 & 15 & 2 & 24 \\
\hline & & Mandrill & 0 & 0 & 0 & 0 & 0 \\
\hline & & Red-capped Mangabey & 2 & 0 & 0 & 0 & 0 \\
\hline & & Greater spot-nosed monkey & 2 & 0 & 2 & 0 & 2 \\
\hline & \multirow[t]{5}{*}{ Mambelé/Lobeke NP } & Chimpanzee & 59 & 11 & 14 & 2 & 23 \\
\hline & & Gorilla & 27 & 1 & 9 & 0 & 10 \\
\hline & & Mandrill & 0 & 0 & 0 & 0 & 0 \\
\hline & & Agile Mangabey & 3 & 1 & 1 & 1 & 1 \\
\hline & & Greater spot-nosed monkey & 1 & 0 & 1 & 0 & 1 \\
\hline Gabon & \multirow[t]{2}{*}{ Matakamangoye } & Chimpanzee & 140 & 9 & 21 & 0 & 30 \\
\hline Total & & & 315 & 39 & 70 & 6 & 103 \\
\hline
\end{tabular}

Abbreviation: $\mathrm{n}$, individuals tested 
a mangabey) branched together but outside of the known filariae and Protospirura muricola DNA references.

\section{Filarial DNA detection in faeces and co-infections with gastro-intestinal nematodes}

Regarding the intestinal nematodes, 106 of the 121 NHPs found to be positive for filariae (87.6\%) were also infected either with Oesophagostomum sp., or Necator sp., or both. In contrast, among the 194 samples in which we could not detect any filariae signals, 151 (77.8\%) were infected with Oesophagostomum sp., or Necator sp. or both. There was no statistically significant association between the presence of infection with these intestinal nematodes and detection of filarial DNA when all NHP species were analysed together or when Cercopithecus sp. and Cercocebus sp. monkeys, mandrills or chimpanzees were analysed separately. However, for the gorillas, we detected significantly more filarial infections when the animals were also infected with gastro-intestinal worms (two-tailed probability $=0.0125$; Tables $2,4,5$ ).

\section{Discussion}

To the best of our knowledge, this is the first study showing that filarial DNA can be detected in the faeces of NHPs using a molecular approach. Among the 315 samples analysed, $121(38.4 \%)$ showed $>90 \%$ homology with Onchocercidae reference sequences. The true infection rates are likely to be even higher, because filariae detection in faecal samples is probably less sensitive than detection in blood. Phylogenetic analyses on cox 1 sequences obtained from five chimpanzee DNA faecal samples from Gabon and two from Cameroon show that these samples cluster together with Mansonella perstans with high bootstrap support. Most of the remaining sequences clustered together within the genus Mansonella, but the species could not be resolved. It has to be noted that most of the studies on filariae infecting NHPs are limited to morphological descriptions and taxonomic analyses at the molecular level are lacking. In wild-living NHPs, adult filariae have been recovered after extraction from lymphatic vessels during necropsies, but these findings remain rare [32]. Because of their localization in host tissues, Mansonella adult stages are difficult to collect and the diversity of this genus is far from being well investigated in animals. Up to now, seven species of Mansonella (M. perstans, M. streptocerca, M. leopoldi, $M$. lopeensis, M. rodhaini, M. gorillae and $M$. vanhoofi) have been described in anthropoids and humans from Africa, based on morphological characteristics only. They all belong to the subgenus Esslingeria [1]. Given the difficulty to recover adult filariae in NHPs, indirect approaches targeting microfilarial DNA could be helpful for their identification [33, 34]. In this study, cox 1 phylogenetic analyses were more informative than $12 S \mathrm{rDNA}$, with sequence fragments of 480 and $280 \mathrm{bp}$, respectively. In this study, we found seven chimpanzee faecal samples infected with M. perstans, a filaria found in humans, while 29 samples of chimpanzees and 21 of gorillas were infected with a Mansonella sp. forming a separate cluster in the cox 1 phylogenetic tree. Using also a DNA barcoding approach based on the ITS marker, a putative new Mansonella species/ subspecies was detected exclusively in febrile children from Gabon [35]. However, by adopting a Sanger sequencing approach, the identification of co-infections with different Mansonella species cannot be resolved in a given individual. In a past morphological study, four Mansonella species were identified in a single male western lowland gorilla (G. gorilla gorilla) found dead in the Lopé Reserve, Gabon [32]. In this animal, female worms of two species of Mansonella (M. lopeensis and Mansonella sp.) were recovered from the deep tissues of the wounded thigh, a single M. leopoldi $\mathrm{mf}$ was found in the blood vessels of the liver, and a male of Mansonella sp. was situated in an afferent lymphatic vessel of an axillary lymph node. Future efforts using next-generation sequencing (NGS) could lower the threshold of detection and improve the sensitivity for detecting low-frequency variants. To date, 14 filarial genomes have been assembled by an NGS approach. A phylogenetic analysis of 41 nematode genomes has been performed, with a consensus tree including 11 out of 14 filarial assemblies. However, no Mansonella sp. assemblies are available yet [36]. Phylogenetic trees have also been constructed from filarial parasite mitogenome sequences [37, 38], comforting the clades described by Lefoulon et al. [2] and the presence of Mansonella sp. in ONC5. The NGS method would also be more suitable to discriminate between a possible multitude of Mansonella spp. parasites and mixed infections with multiple filarial species. Deep sequence analysis represents a potential tool to detect occult infections, as reported in a study where samples classified by traditional methods as $M$. perstans mono-infections were found, through rtPCR and deep sequencing, to also have occult M. ozzardi infections [38].

Mansonella perstans adult filariae are mainly found in in the serous cavities, the visceral adipose tissue or the subcutaneous tissue. However, the microfilariae thrive in the blood and the lymphatic system [39], therefore their detection (or the detection of filarial DNA fragments) in faecal samples, seems surprising. However, a few reports have shown that the adult parasites are usually found in the mesenteries and connective tissues of abdominal organs of humans, gorillas 


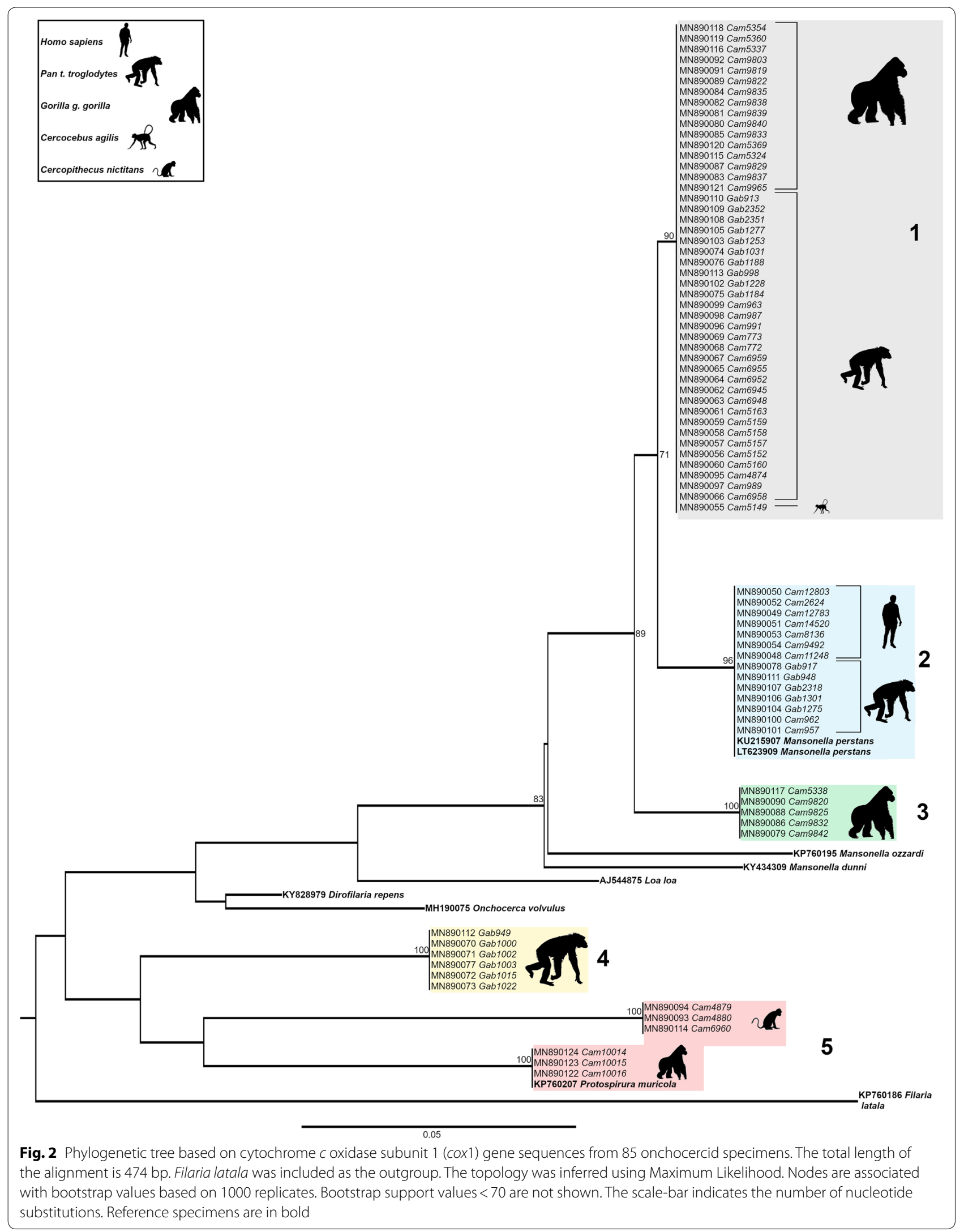




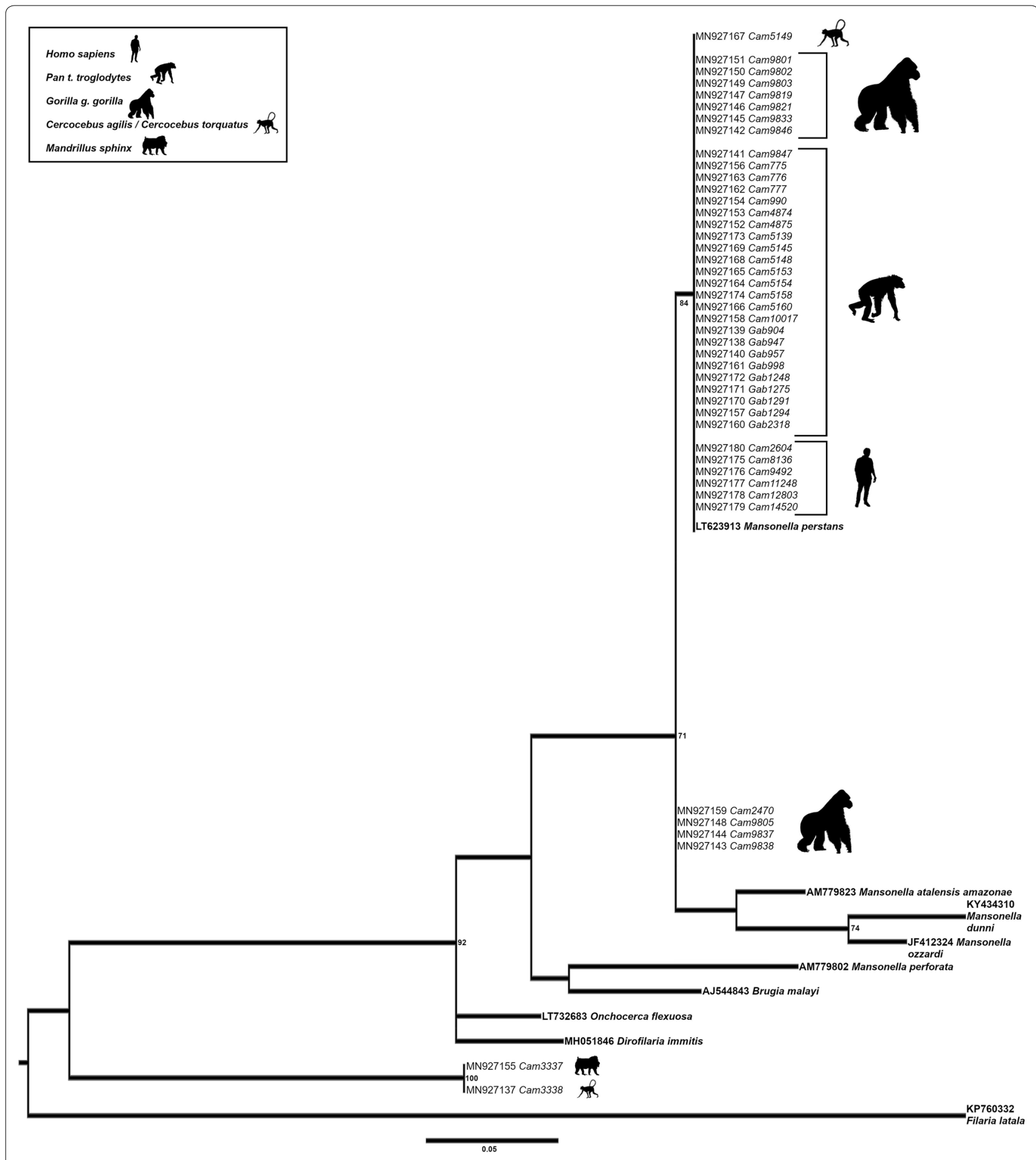

Fig. 3 Phylogenetic tree based on 125 rDNA gene sequences from 52 onchocercid specimens. The total length of the alignment is 266 bp. Filaria latala was included as the outgroup. The topology was inferred using Maximum Likelihood. Nodes are associated with bootstrap values based on 1000 replicates. Bootstrap support values $<70$ are not shown. The scale-bar indicates the number of nucleotide substitutions. Reference specimens are in bold 
Table 4 Association between filariae detection (12S rDNA and cox1) and gastro-intestinal worm infection (ITS2)

\begin{tabular}{llllll}
\hline NHP species & No. of samples tested & 12S/cox1 pos/ITS2neg & 12S/cox1 pos/ITS2pos & 12S/cox1 neg/ITS2neg & $\begin{array}{l}\text { 12S/cox1 neg/ } \\
\text { ITS2pos }\end{array}$ \\
\hline Cercopithecus nictitans & 4 & 0 & 3 & 1 & 0 \\
Cercobebus torquatus/agilis & 12 & 0 & 1 & 5 & 6 \\
Pan troglodytes & 222 & 15 & 70 & 26 & 111 \\
Gorilla gorilla & 65 & 0 & 30 & 7 & 28 \\
Mandrillus sphinx & 12 & 0 & 2 & 4 & 6 \\
Total & 315 & 15 & 106 & 43 & 151 \\
\hline
\end{tabular}

Abbreviations: neg, negative; pos, positive

and chimpanzees [34, 40-43]. In the present study, the detection of parasite DNA in the faecal samples seem not to be associated with the presence of gastrointestinal worms such as Oesophagostomum sp. or Necator sp., except possibly in the gorilla population analysed. The magnitude of Necator sp.-associated pathogenesis and blood loss is highly dependent on the number of adult worms, host immunity and concurrent infections with other nematodes [44]. To properly estimate infection intensity with a particular gastro-intestinal parasite species, invasive collection of adult parasites from the intestines of infected hosts is required, which is indeed impossible in wild endangered animals like apes, with exception of necropsies. Regarding the presence of Oesophagostomum, these infections are usually not associated with intestinal bleeding, although a study reports rectal bleeding due to Oesophagostomum brumpti in a human individual [45] and another study reported intestinal perforation in severe cases of oesophagostomiasis in gorillas [46]. In general, data about clinical manifestations and pathogenesis of any

Table 5 Fisher exact test contingency table and two-tailed probability

\begin{tabular}{llll}
\hline Species & A & C & $\begin{array}{l}\text { Two-tailed } \\
\text { probability }\end{array}$ \\
& $\mathrm{B}$ & $\mathrm{D}$ & 0.233 \\
\hline $\begin{array}{l}\text { Cercopithecus sp/Cercobe- } \\
\text { bus sp. }\end{array}$ & 0 & 4 & \\
Pan troglodytes & 6 & 6 & 0.860 \\
Gorilla gorilla & 15 & 70 & \\
& 26 & 111 & 0.0125 \\
Mandrillus sphinx & 0 & 30 & \\
& 7 & 28 & 0.515 \\
TOTAL & 0 & 2 & 0.036 \\
& 4 & 6 & \\
\hline
\end{tabular}

Abbreviations: A, positive for filariae and negative for GI worms; B, negative for filariae and negative for $\mathrm{Gl}$ worms; $\mathrm{C}$, positive for filariae and positive for $\mathrm{Gl}$ worms; D, negative for filariae and positive for Gl worms strongylid infections in wild NHPs are scarce [47]. Therefore, it remains difficult to draw any conclusion about the association of gastrointestinal worms and the detection of filarial DNA in faeces from gorillas. Studies investigating phytochemical and mechanical properties of plants consumed by NHPs suggest the existence of abrasive properties of certain foliage [47], which could favour the bleeding of the intestine wall and the release of $\mathrm{mf}$ in this body compartment [48]. Lastly, we cannot exclude that the successful detection of filarial DNA in faecal samples may be explained by the presence of cell-free DNA (cfDNA). CfDNA comprises fragments of DNA found extracellularly in the blood circulation but also in different body fluids and tissues. Despite different hypotheses having been presented, the precise origin of cfDNA and how it is distributed remains unclear $[49,50]$.

Finally, we detected the spirurid nematode Protospirura muricola in faecal samples from gorillas and greater spotnosed monkeys. Eggs and fragments of the posterior body of an adult male of $P$. muricola have been found in chimpanzees' faecal samples [51]. Protospirura muricola is a relatively frequent parasite of rodents in Africa and Asia [52-55]. Adults are found in the stomach of the definitive hosts [56]. Dermapterans and most probably also scarabeid beetles are intermediate hosts in the life-cycle of the nematode [57]. Therefore, we cannot exclude with certainty that these faecal samples, laying on the ground before collection, could have been contaminated by $P$. muricola infecting dung beetles or by faecal samples from rodents (the gorilla samples were collected along a road about $500 \mathrm{~m}$ from a small house settlement $\left(2^{\circ} 26^{\prime} 15.828^{\prime \prime}\right.$ $\left.\mathrm{N}, 15^{\circ} 26^{\prime} 19.5^{\prime \prime} \mathrm{E}\right)$ and the $C$. nictitans sample in a cocoa plantation near the village of Mambele $\left(2^{\circ} 23^{\prime} 54.492^{\prime \prime} \mathrm{N}\right.$, $\left.15^{\circ} 30^{\prime} 43.524^{\prime \prime} \mathrm{E}\right)$. However, this parasite has been previously described also in wild NHPs from Nigeria [53] and the Congo [58], in re-introduced chimpanzees in Tanzania [51] and in captive NHPs from south America [59, 60]. Though $P$. muricola in rodents seems to be a relatively non-pathogenic parasite, it causes severe, sometimes fatal, 
disease in captive primates. However, the pathogenicity of the nematode in wild chimpanzees or gorillas remains unknown and it has not been reported in humans.

\section{Conclusions}

To the best of our knowledge, this study shows for the first time that filarial infections can be diagnosed from DNA extracted from faecal material in several NHP species. These preliminary results open up perspectives on the detection of Onchocercidae in samples other than blood and dermal tissues. Such non-invasive sampling, combined with molecular genetic analysis, could allow for investigations of these pathogens in wild animal populations that are difficult to access. Moreover, our results raise questions about the diversity and abundance of these parasites in wildlife and their possible role as sylvatic reservoirs. Similar to other pathogens, which have crossed the species barrier, zoonotic filariae transmission seems possible and could potentially increase [61], especially considering human encroachment into previously pristine territories and the growing proximity between humans and wild animals. Future studies should focus on improving the sensitivity of the tests in both human and NHPs, and improve and extend the molecular information to resolve or support taxonomy classification based on morphological descriptions. Finally, this non-invasive approach should be further tested as a diagnostic alternative in the human population, especially in situations where people are reluctant to undergo blood analysis or where blood tests would require people to engage in long journeys from remote villages to diagnostic centres. Health operators would collect faecal samples at domicile and test a single sample for multiple infections back in a centralized laboratory.

\section{Supplementary information}

Supplementary information accompanies this paper at https://doi. org/10.1186/s13071-020-04184-1.

Additional file 1: Table S1. Accession number (GenBank) list of new filarial species sequences and reference sequences for phylogenetic analyses (cox1 and 12S rDNA).

Additional file 2: Figure S1. Phylogeny of Onchocercidae based on cox1 sequences using Maximum Likelihood inference. The total length of the dataset is $475 \mathrm{bp}$. A total of 86 onchocercid specimens ( 48 sequences from this study with 38 sequences from 38 species from Lefoulon et al. [2]) were analysed. Filaria latala was used as the outgroup. The topology was inferred using Maximum Likelihood, under the general time reversible model, including invariant sites and gamma distribution $(G T R+I+\Gamma)$. Nodes are associated with bootstrap values based on 1000 replicates. The onchocercid subfamilies are indicated by color: blue for Onchocercinae, dark green for Dirofilariinae, purple for Splendidofilariinae, yellow for Waltonellinae. Although the cox1 gene is not informative enough for deeper phylogenies it is for species level phylogenies and onchocercid clades described in Lefoulon et al. [2] are identifiable, especially ONC5 to which belong the new sequences.

\section{Abbreviations}

AIC: Akaike information criterion; BLASTn: Nucleotide Basic Local Alignment Search Tool; BSA: Bovine serum albumin; cfDNA: cell-free DNA; cox1: cytochrome $c$ oxidase subunit $1 ; G T R+I+\Gamma$ : general time-reversible plus invariant sites plus gamma distributed model; ITS2: internal transcribed spacer 2; LAMP: loop-mediated isothermal amplification; ML: Maximum Likelihood; mf: microfilariae; NGS: next-generation sequencing; NHP: non-human primates; (rt)PCR: (real time) polymerase chain reaction; SIV: simian immunodeficiency virus.

\section{Acknowledgements}

We are grateful to the staff of the SIV team from PRESICA, Hugues Nana Djeunga and Joseph Kamgno from CFilMT, Cédric Chesnais and Luc Abate (IRD) for samples and logistical support in Cameroon and the Cameroonian Ministries of Public Health and of Environment and Forestry. We thank Alain-Prince Okouga, Philippe Engandja and Vanina Boué for technical and logistic support in Gabon, and the Ministry of Water and Forests of Gabon, and also to Laetitia Serrano and Maxime Doret for technical support with DBS DNA extraction and analysis. The authors would like to thank the editor and reviewer for their valuable comments and suggestions on an earlier version of the manuscript.

\section{Authors' contributions}

$\mathrm{SL}$ conceived and designed the experiments. CMG, HH, CS, CB, TL, AE and $S L$ performed the experiments. CMG, SDP, JR, CM and SL analysed the data. IM, FL, MP and EMN contributed reagents/materials/analysis tools. CMG, SDP, CM, MB and SL wrote the paper. All authors read and approved the final manuscript.

\section{Funding}

This work was supported in part by grants from the National Institute of Health (RO1 Al 50529), the Agence Nationale de Recherches sur le SIDA (ANRS 12125/12182/12325), by the Centre International de Recherches Médicales de Franceville (CIRMF) and the Institut de Recherche pour le Développement (IRD).

\section{Availability of data and materials}

All data generated or analysed during this study are included in this article and its additional files. We deposited all newly generated sequences from this study in the GenBank database under the accession numbers: MN890048MN890124 (cox1) and MN927137-MN927180 (12S rDNA) (Additional file 1: Table S1). The datasets on Oesophagostomum spp. and Necator spp. used and/ or analysed during the present study are available from the corresponding author on reasonable request.

\section{Ethics approval and consent to participate}

Non-human faecal samples were collected non-invasively, around nests, food sites, or on traces, on the forest floor. Human blood positive samples for $\boldsymbol{M}$. perstans were included as controls, but collected specifically for a different study (unpublished). They were provided by third parties, collected in the Okola Health District, in the Centre region of Cameroon, under the approval of the regional ethical committee (No. 00828).

\section{Consent for publication}

Not applicable.

\section{Competing interests}

The authors have declared that they have no competing interests.

\section{Author details}

${ }^{1}$ IRD UMI 233-INSERM U1175, University of Montpellier, Montpellier, France. ${ }^{2}$ Unité Molécules de Communication et Adaptation des Microorganismes (MCAM UMR7245), Muséum national d'Histoire naturelle, CNRS, Paris, France. ${ }^{3}$ Projet Prévention du Sida au Cameroun (PRESICA) and Virology Laboratory IMPM/IRD, Yaoundé, Cameroon. ${ }^{4}$ Centre International de Recherches Médicales, BP 769 Franceville, Gabon. ${ }^{5}$ Laboratoire Maladies Infectieuses et Vecteurs: Ecologie, Génétique, Evolution, Contrôle, UMR 224 IRD/CNRS/UM1, 34394 Montpellier, France.

Received: 15 January 2020 Accepted: 12 June 2020

Published online: 16 June 2020 


\section{References}

1. Bain O, Mutafchiev Y, Junker K, Guerrero R, Martin C, Lefoulon E, et al. Review of the genus Mansonella Faust, 1929 sensu lato (Nematoda: Onchocercidae), with descriptions of a new subgenus and a new subspecies. Zootaxa. 2015:3918:151-93.

2. Lefoulon E, Bain O, Bourret J, Junker K, Guerrero R, Canizales I, et al. Shaking the tree: multi-locus sequence typing usurps current onchocercid (filarial nematode) phylogeny. PLoS Negl Trop Dis. 2015;9:e0004233.

3. Kamgno J, Pion SD, Chesnais CB, Bakalar MH, D'Ambrosio MV, Mackenzie $C D$, et al. A test-and-not-treat strategy for onchocerciasis in Loa loaendemic areas. N Engl J Med. 2017;377:2044-52.

4. Drame PM, Montavon C, Pion SD, Kubofcik J, Fay MP, Nutman TB. Molecular epidemiology of blood-borne human parasites in a Loa loa-, Mansonella perstans-, and Plasmodium falciparum-endemic region of Cameroon. Am J Trop Med Hyg. 2016;94:1301-8.

5. Poole CB, Li Z, Alhassan A, Guelig D, Diesburg S, Tanner NA, et al. Colorimetric tests for diagnosis of filarial infection and vector surveillance using non-instrumented nucleic acid loop-mediated isothermal amplification (NINA-LAMP). PLoS One. 2017;12:e0169011.

6. Deng MH, Zhong LY, Kamolnetr O, Limpanont Y, LV ZY. Detection of helminths by loop-mediated isothermal amplification assay: a review of updated technology and future outlook. Infect Dis Poverty. 2019;8:20.

7. Lagatie O, Merino M, Batsa Debrah L, Debrah AY, Stuyver LJ. An isothermal DNA amplification method for detection of Onchocerca volvulus infection in skin biopsies. Parasit Vectors. 2016;9:624.

8. Lefoulon E, Giannelli A, Makepeace BL, Mutafchiev Y, Townson S, Uni S, et al. Whence river blindness? The domestication of mammals and hostparasite co-evolution in the nematode genus Onchocerca. Int J Parasitol. 2017:47(8):457-70.

9. Prugnolle F, Durand P, Neel C, Ollomo B, Ayala FJ, Arnathau C, et al. African great apes are natural hosts of multiple related malaria species, including Plasmodium falciparum. Proc Natl Acad Sci USA. 2010;107:1458-63.

10. Abkallo HM, Liu W, Hokama S, Ferreira PE, Nakazawa S, Maeno Y, et al. DNA from pre-erythrocytic stage malaria parasites is detectable by PCR in the faeces and blood of hosts. Int J Parasitol. 2014;44:467-73.

11. Jirku M, Pomajbikova K, Petrzelkova KJ, Huzova Z, Modry D, Lukes J. Detection of Plasmodium spp. in human feces. Emerg Infect Dis. 2012;18:634-6.

12. Hasegawa H, Modry D, Kitagawa M, Shutt KA, Todd A, Kalousova B, et al. Humans and great apes cohabiting the forest ecosystem in central african republic harbour the same hookworms. PLoS Negl Trop Dis. 2014;8:e2715.

13. Makouloutou P, Mbehang Nguema PP, Fujita S, Takenoshita Y, Hasegawa $H$, Yanagida T, et al. Prevalence and genetic diversity of Oesophagostomum stephanostomum in wild lowland gorillas at Moukalaba-Doudou National Park, Gabon. Helminthologia. 2014;51:83-93.

14. Hotez PJ, Brooker S, Bethony JM, Bottazzi ME, Loukas A, Xiao S. Hookworm infection. N Engl J Med. 2004;351:799-807.

15. Mapua MI, Pafco B, Burgunder J, Profousova-Psenkova I, Todd A, Hashimoto C, et al. No impact of strongyloides infections on the detection of Plasmodium spp. in faeces of western lowland gorillas and eastern chimpanzees. Malar J. 2017;16:175

16. Neel C, Etienne L, Li Y, Takehisa J, Rudicell RS, Bass IN, et al. Molecular epidemiology of simian immunodeficiency virus infection in wild-living gorillas. J Virol. 2010;84:1464-76.

17. Boue V, Locatelli S, Boucher F, Ayouba A, Butel C, Esteban A, et al. High rate of simian immunodeficiency virus (SIV) infections in wild chimpanzees in northeastern Gabon. Viruses. 2015;7:4997-5015.

18. van der Kuyl AC, Kuiken CL, Dekker JT, Goudsmit J. Phylogeny of African monkeys based upon mitochondrial 12S rRNA sequences. J Mol Evol. 1995:40:173-80

19. Etienne L, Locatelli S, Ayouba A, Esteban A, Butel C, Liegeois F, et al. Noninvasive follow-up of simian immunodeficiency virus infection in wild-living nonhabituated western lowland gorillas in Cameroon. J Virol. 2012;86:9760-72.

20. Sullivan KM, Mannucci A, Kimpton CP, Gill P. A rapid and quantitative DNA sex test: fluorescence-based PCR analysis of X-Y homologous gene amelogenin. Biotechniques. 1993;15:636-41.

21. Monleau M, Aghokeng AF, Eymard-Duvernay S, Dagnra A, Kania D, NgoGiang-Huong N, et al. Field evaluation of dried blood spots for routine
HIV-1 viral load and drug resistance monitoring in patients receiving antiretroviral therapy in Africa and Asia. J Clin Microbiol. 2014;52:578-86.

22. Ferri G, Alu M, Corradini B, Licata M, Beduschi G. Species identification through DNA "barcodes". Genet Test Mol Biomarkers. 2009;13:421-6.

23. Casiraghi M, Labra M, Ferri E, Galimberti A, De Mattia F. DNA barcoding: a six-question tour to improve users' awareness about the method. Brief Bioinform. 2010;11:440-53.

24. Lefoulon E, Gavotte L, Junker K, Barbuto M, Uni S, Landmann F, et al. A new type F Wolbachia from Splendidofilariinae (Onchocercidae) supports the recent emergence of this supergroup. Int J Parasitol. 2012;42:1025-36.

25. Casiraghi M, Anderson TJ, Bandi C, Bazzocchi C, Genchi C. A phylogenetic analysis of filarial nematodes: comparison with the phylogeny of Wolbachia endosymbionts. Parasitology. 2001;122:93-103.

26. Ghai RR, Chapman CA, Omeja PA, Davies TJ, Goldberg TL. Nodule worm infection in humans and wild primates in Uganda: cryptic species in a newly identified region of human transmission. PLoS Negl Trop Dis. 2014;8:e2641.

27. Gasser RB, Chilton NB, Hoste H, Beveridge I. Rapid sequencing of rDNA from single worms and eggs of parasitic helminths. Nucleic Acids Res. 1993:21:2525-6.

28. Romstad A, Gasser RB, Monti JR, Polderman AM, Nansen P, Pit DS, et al. Differentiation of Oesophagostomum bifurcum from Necator americanus by PCR using genetic markers in spacer ribosomal DNA. Mol Cell Probes. 1997;11:169-76.

29. Nucleotide BLAST: search nucleotide databases using a nucleotide query. https://blast.ncbi.nlm.nih.gov/Blast.cgi?PAGE_TYPE=BlastSearch. Accessed 12 Jan 2020.

30. Edgar RC. MUSCLE: multiple sequence alignment with high accuracy and high throughput. Nucleic Acids Res. 2004;32:1792-7.

31. Posada D. jModelTest: phylogenetic model averaging. Mol Biol Evol. 2008;25:1253-6.

32. Bain $\mathrm{O}$, Moisson P, Huerre M, Landsoud-Soukate J, Tutin C. Filariae from a wild gorilla in Gabon with description of a new species of Mansonella. Parasite. 1995;2:315-22.

33. Chabaud AG, Bain O. La lignée Dipetalonema. Nouvel essai de classification Ann Parasitol Hum Comp. 1976;51:365-97.

34. Van den Berghe L, Chardome M, Peel E. Dipetalonema gorillae n. sp., filaire de Gorilla gorilla au Congo Belge. Folia Sci Afr Cent. 1957;3:87.

35. Mourembou G, Fenollar F, Lekana-Douki JB, Ndjoyi Mbiguino A, Maghendji Nzondo S, Matsiegui PB, et al. Mansonella, including a potential new species, as common parasites in children in Gabon. PLoS Negl Trop Dis. 2015:9:e0004155.

36. Senanayake KS, Soderberg J, Polajev A, Malmberg M, Karunanayake $\mathrm{EH}$, Tennekoon $\mathrm{KH}$, et al. The genome of Setaria digitata: a cattle nematode closely related to human filarial parasites. Genome Biol Evol. 2020;12:3971-6.

37. Crainey JL, Marin MA, Silva T, de Medeiros JF, Pessoa FAC, Santos YV, et al. Mansonella ozzardi mitogenome and pseudogene characterisation provides new perspectives on filarial parasite systematics and $\mathrm{CO}-1$ barcoding. Sci Rep. 2018;8:6158

38. Crainey JL, Costa CHA, de Oliveira Leles LF, Ribeiro da Silva TR, de Aquino Narzetti LH, Serra Dos Santos YV, et al. Deep-sequencing reveals occult mansonellosis co-infections in residents from the Brazilian Amazon village of Sao Gabriel da Cachoeira. Clin Infect Dis. 2020:ciaa082.

39. Ta-Tang TH, Crainey JL, Post RJ, Luz SL, Rubio JM. Mansonellosis: current perspectives. Res Rep Trop Med. 2018;9:9-24.

40. WHO. Bench aids for the diagnosis of filarial infections. Geneva: World Health Organization; 1997.

41. Berghe L, Van den Chardome M, Peel E. Microfilaria leopoldi n. sp. chez Gorilla gorilla au Congo Belge. Folia Scientif Afr Centr. 1957;3:87.

42. Baird JK, Neafie RC, Lanoie L, Connor DH. Adult Mansonella perstans in the abdominal cavity in nine Africans. Am J Trop Med Hyg. 1987;37:578-84.

43. Peel E, Chardome M. Sur les Filaridés de Chimpanzés Pan paniscus et Pan satyrus au Congo Belge. Ann Soc Belge de Med Trop. 1946;26:117-56.

44. Cabaret J, Gasnier N, Jacquiet P. Faecal egg counts are representative of digestive-tract strongyle worm burdens in sheep and goats. Parasite. 1998;5:137-42.

45. Leoutsakos B, Agnadi N, Kolisiatis S. Rectal bleeding due to Oesophagostomum brumpti: report of a case. Dis Colon Rectum. 1977:20:632-4.

46. Van den Berghe L, Chardome M, Peel E. The filarial parasites of the eastern gorilla in the Congo. J Helminthol. 1964;38:349-68. 
47. Krief S, Jamart A, Mahe S, Leendertz FH, Matz-Rensing K, Crespeau F, et al. Clinical and pathologic manifestation of oesophagostomosis in African great apes: does self-medication in wild apes influence disease progression? J Med Primatol. 2008;37:188-95.

48. Huffman MA, Gotoh S, Turner L, Yoshida K. Seasonal trends in intestinal nematode infection and medicinal plant use among chimpanzees in the Mahale Mountains, Tanzania. Primates. 1997;38:111-25.

49. Weerakoon KG, McManus DP. Cell-Free DNA as a diagnostic tool for human parasitic infections. Trends Parasitol. 2016;32:378-91.

50. Oi M, Sato Y, Nakagaki K, Nogami S. Detection of Dirofilaria immitis DNA in host serum by nested PCR. Parasitol Res. 2015;114:3645-8.

51. Petrzelkova KJ, Hasegawa H, Moscovice LR, Kaur T, Issa M, Huffman MH. Parasitic nematodes in the chimpanzee population on Rubondo Island, Tanzania. Int J Primatol. 2006;27:767.

52. Gedoelst L. Notes sur la faune parasitaire du Congo Belge Rev Zool Afr. 1916:5:1-90.

53. Baylis HA. On a collection of nematodes from Nigerian mammals (chiefly rodents). Parasitology. 1928;20:208-304.

54. Morel PC. Les helminthes des animaux domestiques de I'Afrique occidentale. Rev Elev Med Vet Pays Trop. 1959;12:153-74

55. Tubangui MA. Worm parasites of the brown rat (Mus norvegicus) in the Philippine Islands with a special reference to those forms that may be transmitted to human beings. Philippine J Sci. 1931;46:537-92.
56. Tenora F, Barus V, Prokes M, Sumbera R, Koubkova B. Helminths parasitizing the silvery mole-rat Heliophobius argenteocinereus (Rodentia: Bathyergidae) from Malawi. Helminthologia. 2003;40:153-60.

57. Anderson RC. Nematode parasites of vertebrates: their development and transmission. 2nd ed. Wallingford: CABI Publishing; 2000

58. Vuylsteke A. Note sur quelques Nématodes parasites avec description de neuf especes nouvelles. Rev Zool Bot Afr. 1956;53:441-77.

59. Foster $\mathrm{AO}$, Johnson CM. A preliminary note on identity, life cycle, and pathogenicity of an important parasite of captive monkeys. Am J Trop Med Hyg. 1939;19:265-77.

60. Dollfus RP, Chabaud AG. Cinq especes de nématodes chez un atele [Ateles ater (G. Cuvier 1823)] mort a la ménagerie du museum. Arch Mus Hist Nat. 1955;3:27-40.

61. Nelson GS. Filarial infections as zoonoses. J Helminthol. 1965;39:220-50.

\section{Publisher's Note}

Springer Nature remains neutral with regard to jurisdictional claims in published maps and institutional affiliations.
Ready to submit your research? Choose BMC and benefit from:

- fast, convenient online submission

- thorough peer review by experienced researchers in your field

- rapid publication on acceptance

- support for research data, including large and complex data types

- gold Open Access which fosters wider collaboration and increased citations

- maximum visibility for your research: over 100M website views per year

At BMC, research is always in progress.

Learn more biomedcentral.com/submissions 